\title{
METHOD OF TAX AUDIT OF CERTAIN CATEGORIES OF TAXPAYERS BY STATE FISCAL SERVICE OF UKRAINE
}

\author{
Bohdan KOSTIUK', \\ Kyiv National University of Trade and Economics, Ukraine
}

\begin{abstract}
Tax audit is an important part of tax control. It's aimed to control the observance of tax legislation on taxes and fees. The purpose of the research is to generalize the method of performance of tax audits of individual taxpayers by State Fiscal Service of Ukraine. The subject of research is the methods of audit by State Fiscal Service of Ukraine. Methods. It was used general and specific methods of research, including: analysis and synthesis, system and process approaches, induction and deduction, etc. Results. The problem of tax auditing process in Ukraine is the absence of integrated and systematic approach for its implementation. Unfortunately, the practice of the tax audit is not yet examined clearly. Today the basic principles of tax audit are considered by the scientists only in theory. Apart from the existence of guidelines on verification of a particular type of taxes, other obligatory payments that are designed fiscal service, the formation of evidence, procedure for using certain methods and techniques for auditing, information sources are ignored legislators and scientists. Apart from the existence of guidelines on verification of a particular type of taxes, other obligatory payments which are designed by fiscal service, the formation of evidence base, procedure of usage of certain methods and techniques for audit, information sources and other issues are ignored by legislators and scientists. Despite this, today the tax audit is a tool to fully examine and reduce the tax risks of the organization. Another problem of tax audit is that legislation doesn't fix the notion of tax audit so there is no exact interpretation of it. Tax audit engages more efficient flow of taxes and fees to the state budget. Although there is increase of the efficiency of the national tax auditing mechanism now, but there are some problems which need be resolved in order to ensure rational tax revenues in the budget under the present conditions of socio-economic and political reforms in Ukraine. To further improvement of tax audit it should be applied new progressive methods of influence on taxpayers which is intended to limit the participation of tax payer in tax process and to reduce its potential capability to minimize tax liabilities. The practical significance of the study is determination of recommendations for improvement of the method of selection of taxpayers for tax audits. Value/originality. Information on methods of tax audit which was obtained in the study can be used in further studies on improvement of tax administration.
\end{abstract}

Key words: tax audit, taxpayer, cameral tax audit, control, code.

JEL Classification: R14, D18, P2

\section{Introduction}

Today economic reforms in Ukraine are carried out against the aggravation of financial crisis, in addition with political crisis in the country. Social tension is increasing sharply. The changes made in tax legislation are aimed primarily at increase of revenue part of the budget and reduce of the expense budget for the authorities.

Entities are accustomed to frequent changes in legislation and have learned to adapt to them. Therefore, taxpayers should use effective methods of tax control as an effective tool for identification of tax offenses. Tax audit should solve the problem of Ukrainian economics deshadowing (legalization of incomes of all market participants), reduce of tax debts and balance of tax system in general.

\section{Role of the tax audit in the tax control process}

Tax control is an independent kind of financial control directed to ensure the compliance with tax and other legislation by taxpayers, detection, elimination and prevention of tax offenses. The main purpose of tax control in modern Ukraine is the constant revenue part of the budget. One of the components of tax control in Ukraine is a tax audit.

Despite the definition of "tax audit" is often used in specialized literature and in everyday activity of audit companies, it does not have the only correct and reasonable interpretation. Current national legislation and Audit International Standards don't show the content of tax audit. Thus, analysis of the current legislation of Ukraine

\footnotetext{
Corresponding author:

${ }^{1}$ Department of Financial Analysis and Control, Kyiv National University of Trade and Economics.

E-mail: kostyk1991@gmail.com
} 
indicates a lack of definition of a tax audit in it, while the notion of "inspection" is used.

In particular, the Article 19 of the Tax Code of Ukraine has only one mention of the possibility to perform tax audit by offices of State Fiscal Service of Ukraine (hereinafter SFS) in Ukraine. In particular, Article 19.1.39 establishes that among the functions of supervisory authorities they are entitled to perform institutional control and internal audit over compliance with legislation and the performance of official duties by regulatory bodies, enterprises, institutions and organizations belonging to the their management(Tax Codex of Ukraine, 2010).

There is a difference between definitions of "tax audit" in the specialized literature. Usually, scientists consider it in two ways, as a feature or element of financial control and as oversight of the tax laws.

Tax audit is verification of accuracy, timeliness and completeness of tax calculations per applicable legislation, completeness and correctness of formation and submission to the tax authorities of all forms tax reporting (Petrik, 2012). Verification of tax liability could be done by tax audit or by confirmed procedures on verification of calculation of tax liabilities. The importance of tax audit for a company is an assessment of tax risks timely and negating them.

Thus, it should be noted that today there is a lack of proper scientific justification of conceptual basis of the tax audit, methodological support and legislative regulation. This situation leads to ambiguous interpretation of the essence of tax audit in the structure of tax auditing. Therefore, further development of the national tax audit needs, above all, its exact definition and deep examination to improve the theory and practice of auditing.

\section{Tax inspection is the main form of tax audit}

There are three methods of tax control in Ukrainian legislation:

1) accounting of the taxpayers,

2) information and analytical support of the STS and

3) tax checks.

Detail forms of inspections are specified in the Article 75 of Tax Code of Ukraine, according to which there are cameral, documentary and factual inspections. Depending on the frequency and timing there are scheduled and unscheduled inspections, and depending on the place of control actions of authorized body's - on-site and off-site inspections (Tax Codex of Ukraine, 2010). Furthermore, according to the Tax Code of Ukraine, another kind of documentary unscheduled off-site inspection is inspection in electronic form, which is performed according to application of the taxpayer submitted 10 days before the expected start of its performance.

Organization of on-site tax inspection refers to a set of measures on preparation and planning of on-site tax audit; division of responsibilities between the participants of inspection group; a plan (program) of its holding; immediate verification of all planned issues; presentations of results; measures to remove and prevent tax offenses.

The nature of the activities carried out by the tax authority within inspection process, is proposed to consider according its separate stage, among which there are:

1) preparatory phase (the effectiveness of tax inspection depends on the choice of object, the readiness of each participant to inspect and distribution of the group according to specific areas);

2) holding of inspection;

3) presentation of the materials of inspection.

The most ordinary kind of tax inspection is cameral inspection. It is held in the office of SFS bodies solely on the basis of tax declarations (calculations) of the taxpayer. In other words, consent for its holding or direct participation of the taxpayer in this case is not required and presentation of any direction of conduct of cameral inspection or special decision of the head of the supervisory body is not required. Within cameral inspection it is conducted the analysis of all tax reporting of the taxpayer and in case of violations it is drawn up an act in two copies signed by the officials who conducted the inspection. After registration of it in the SFS this act is given or sent by mail within three business days to the taxpayer for signing in established manner (Revutsky, 2009).

Special attention should be paid to procedures of document exchange between the taxpayer and the supervisory authority. Legal regulation of information exchange between taxpayers and the regulatory authorities has always been important. This is due primarily to the value of such exchange for legal arrangement between these entities. Often the receipt or non-receipt of documents from one party to another is legal fact, which can generate not only financial and legal relations, but also administrative or even criminal. In this context it refers to the improper performance of tax obligation, which entails the liability.

The attention should be paid on fundamental difference between documentary and cameral inspections from real ones - provisions of different laws regulate the procedure of their appointment and conduct. If the camera and documentary inspections are conducted by SFS bodies only in cases and in the manner prescribed by the Tax Code of Ukraine, the procedure for conducting the ex post inspections can be additionally established and detailed by other laws of Ukraine, the enforcement of which is of entrusted to the SFS. This leads to the formulation of regulatory uncertainty in possibility of tax audits and, in fact, it is contrary to the provisions of part 1 , Article 61.3 of the Tax Code of Ukraine, according to which bodies of the State Securities Service, Ministry of Internal Affairs, Tax police, Prosecutors and their official person cannot take a direct part in inspections carried out by supervisory authorities, and conduct inspections of entities on tax matters.

The ex post inspection is the inspection held at the place of actual taxpayer activity, disposal of economic or other objects of property of such taxpayer. This kind of tax audit is carried out by the SFA bodies in compliance with the legislation on cash turnover, the procedure of taxpayers 
payment transactions, cash transactions, availability of licenses, patents, certificates, including the production and circulation of excise goods, compliance with legislation on an employment contract, registration of labour relations with employees by the employer.

The documentary inspection is inspection the subject of which is accuracy, timeliness, completeness of accrual payment of all taxes and fees defined by the Tax Code of Ukraine. There are following issues for documentary inspection:

- tax declarations (calculations);

- financial, statistical and other reporting;

- registers of tax and accounting management of which is provided by law;

- primary documents used in accounting and tax accounting and related with accrual and payment of taxes and fees;

- obtained in accordance with law by the state tax service of documents and tax information.

One of the innovations introduced by the Law № 5083VI to Tax Code of Ukraine is the implementation of electronic inspections. According to paragraph 10, section XX of Tax Code of Ukraine, electronic inspections can be carried with taxpayers who:

- use simplified system of taxation, accounting and reporting - from 01.01.2014;

- entities of micro, small and medium businesses - from 01/01/2015;

- other taxpayers - from 01.01.2016 (Tax Codex of Ukraine, 2010).

In accordance with paragraph 75.1.2 of Tax Codex of Ukraine documentary unscheduled off-site inspection is inspection which is based on the application submitted by the taxpayer with little risk determined in accordance with the Tax Code of Ukraine to the SFS where it is on tax accounting.

So, electronic inspection will be conducted in the unscheduled process according to the initiative of taxpayer. This should be presented by its application. Such declaration is provided within 10 calendar days prior to the expected start of the electronic inspection. Secondly, only taxpayers with little risk have the right to start electronic inspection; taxpayers of simplified system of taxation, accounting and reporting are inspected since 01.01.2014.

The main advantage of electronic inspection is that taxmen will not independently calculate the tax liability for the results. In other words, in case of understatement of tax liabilities by SFS body in the result of their conduct the taxpayer should pay sp called "self-penalty" and fine just under the paragraph. 50.1 Tax Code of Ukraine.

Resolution on documentary scheduled, unscheduled and ex post inspections is approved by the head of SFS body according to the Articles 77, 78, 79 and 80 of Section II of the Tax Code with indication of the subject (object), which is inspected, goals, the type of inspection, the grounds for inspection, start dates (except the ex post inspections) and duration of the inspection which is approved by the order meeting the requirements of the Tax Code.

\section{Method of selection of taxpayers for tax audits}

There are different methods for taxpayer's audits selection. K. Schwabiy, N. Novitskaya offers following classification of these methods:

- random selection;

- inspection according to the data obtained from sources of suggestive information («method of alerts $»)$;

- inspection of the largest taxpayers;

- analysis of taxpayers (comparison of data which the taxpayer stated in his tax return with information obtained from other sources);

- inspection of those taxpayers whose previous audits found significant concealment of income;

- inspection of all companies in a particular industry (Schwabiy, Novitskaya, 2007).

It can be used as one method as in combination with others methods. For example, it is used as random method when the tax inspector selects entity which will be inspected from the indeterminate amount of taxpayers chosen by computer system, as the method of «alerts» when taxpayers about which there is information on their high probability of tax violations are inspected in Canada and Germany; in Poland the method of sectoral inspections is often used when it is inspected all companies within the top-priority industry (construction, oil, transport, etc.), in the Western Europe and the US it is widely used the method of analysis, when all information about financial and economic activity of both legal and natural persons is provided to the common data base and in case of tax violations such entities or persons are inspected.

Methods of taxpayer's selection before inspections in Ukraine are fully depended on criteria. For scheduled inspections taxpayers are selected according to the system of early detection and termination of the shadow economy and destruction of tax minimization schemes, which provides remote audit of threats of tax evasion through analysis of available databases using special computer programs («risk-oriented system»), established in 2008 by Methodical recommendations for plan scheduled inspections of entities which was approved by the State Tax Administration of Ukraine \#162 on 15.03.2010.

Taxpayer's selection algorithm is based on a comprehensive consideration and qualitative information which is held by SFS bodies and determination of degrees of risk of commitment of tax violations. Risk-oriented system would allow to select entities from the total number of taxpayers according to certain criteria who have the risk of commitment of tax violations without the intervention to the financial and economic activities of entities.

The main criterion for selection of taxpayers to the plan of scheduled documentary off-site inspections under this system is a risk of commitment of tax violation by an entity. Therefore, the method of selection of taxpayers for the scheduled documentary off-site inspections is a method of analysis - information on a taxpayer, which is at the disposal of SFS bodies is analysed, in the result of which it 
is selected taxpayers with the risks of non-payment of taxes or commitment of tax violations (Dmitrenko, 2012).

The selection of taxpayers for the unscheduled documentary off-site inspections is carried out not by the criteria but for base established by law the presence of which is the reason for such inspections. In particular, according to the Article 78 of the Tax Code of Ukraine the reasons which are the basis for tax inspection are:

- availability of information indicating tax violations by taxpayer;

- organizational and legal changes in the activity of the taxpayer;

- request of another authority or person to conduct inspections;

- supervision of the inspections.

So, for unscheduled documentary off-site inspections the taxpayers are selected not according to the risk of commitment of violations by the entity but according to the information on the commitment of tax violation by the entity which is indirectly confirmed by information which is held by SFS and it is necessary to confirm or deny by inspection of its financial and business documents which can be done only during the tax inspection.

Performance of unscheduled documentary off-site inspections may take place at the initiative of the SFS bodies as well as other bodies (court, inquiry body, investigator, prosecutor). This initiative of SFS bodies can be as the result of following issues:

1) information indicating tax violations by entity;

2) results of inspection of documents of mandatory reporting of taxpayer or documents of documentary inspection performed by SFS bodies of higher level in order of control of the activity or inactivity of officials of SFS of lower level, during which it was found the incompliance of results of the inspection report with legislation or with incomplete clarification of issues of inspection which should to be clarified during inspection for making an objective conclusion on taxpayer's compliance with legal requirements, enforcement of which is entrusted to the SFS bodies;

3) demand of a taxpayer when he submits to the SFS body objections to the inspection report or complaint made on results of tax notification-resolution, which need full or partial revision of the results of relevant inspection or cancellation of results of tax notification-resolution, where the taxpayer refers to circumstances in his complaint which were not examined during the audit, and their objective examination is impossible without inspection.

Consequently, the reasons for unscheduled documentary inspections can be classified as (1) initiative reasons which are undertaken by SFS bodies for the availability of information on tax violations in the activities of the entity and (2) obligatory reasons which are undertaken at the request of the relevant authorities, or upon the occurrence of certain circumstances. The selection of taxpayers for unscheduled off-site tax inspections is only possible if the initiative inspections, as procedural mechanism of preparation for inspection require the head of the SFS body to make a decision on its implementation. Criteria for such selection are not defined by law (Petrik, 2012).

We offer to apply the criterion of economic efficiency of future inspections which consists in conformity of the aim (i.e. it is necessary to select those taxpayers whose chance of detecting violations is higher and the volume of more accruals will be the greatest) within selection of taxpayers for initiative unscheduled documentary off-site inspections. Applying this criterion also takes into account the cost of work of fiscal authority's employees to conduct unscheduled off-site tax inspections.

Grounds for conducting ex post inspections which are established in Article 80 of Tax Code of Ukraine can be systematized as follows:

- availability of information which may show tax violations by the taxpayer;

- obtaining of information from external sources about tax violation by taxpayer which is supervised by the SFS bodies («alert messages»).

Thus, as within unscheduled documentary off-site tax inspections, the criteria of selection of taxpayers for ex post inspections is not the risk of commitment of tax violations by the entity, but availability of information about commitment of tax violation by the entity to confirm or deny conduct of ex post inspection.

The method of selection of taxpayers for conducting ex post inspections, in addition to analysis of information on taxpayers, is also a method of «alert messages» when inspection is carried out on data obtained from external sources which show tax violation by taxpayer, supervision of which is entrusted to the SFS bodies.

In 2014 , the only principle of selection of entities to the plan of inspections was the presence of their financial and economic risks of non-payment of fees to the budget. So, scheduled inspections were aimed solely to those companies which do not pay deliberately or pay payments not in full size to the budget, using the scheme to reduce or tax evasion. This approach has allowed to cut the number of planned inspections.

The principal methods of selecting taxpayers for off-site tax inspections are:

1) the method of analysis of information about the taxpayers; 2) the method of economic efficiency of future inspection; 3) the method of «alarm messages $»$.

\section{Conclusions}

Today the process of further improvement of tax control methods and techniques of control ways continues. This process takes into account not only the experience of earlier years of tax service, but also the practice of tax services of other countries. To meet these goals it is established and gradually implemented new technologies of tax activity which are based on the use of modern computer technology. They are directed to the systematic and effective use of internal and external information for scheduled inspections and qualitative performance of audit functions, and on the effective counteraction to tax evasion, the elimination of the shadow economy. 


\section{References}

Tax Code of Ukraine of 02.12.2010, № 2755-VI (amended on 03.04.2014 g.). Bulletin of the Verkhovna Rada of Ukraine. - 2011. - № 13-14, № 15-16, № 17. - Ct. 112.

Dimitrenko, E.V. (2012). Tax audit service as a service of the State Tax Service and the most effective form of tax control.Investment: practice and experience, № 19, p. 41-45.

Lebedynets, T. (2013). The role of internal audit in preventing and detecting fraud. The independent auditor, № $7(18)$, p. 60-63.

Naidenko, O.E. (2012). Tax control: a tutorial. - H., ed. KhNUE, 224 p.

Peter, A.A. (2012). Essence audit taxation under the rules of the Tax Code of Ukraine and the order of organization. Electronic scientific archive of the Scientific and Technical Library of National University «Lviv Polytechnic», p. 190-197.

Proskura, K.P. (2013). Organization and guidance of a tax audit as part of tax control. The independent auditor, № 5(III), p. 43-48.

Revutsky, L.V. (2009). Analysis of efficiency practices of tax audit in Ukraine. Bulletin Khmelnytsky National University, № 4, p. 104-107.

Fradynskyy, O.A. (2013). Comparative characteristics of inspections during tax audits and customs. Proceedings of the International Scientific Conference [ $\ll$ Strategic directions of socio-economic development in conditions of globalization»] (Khmelnytsky, 18-20 April 2013). - Khmelnitsky, Khmelnytsky University of Management and Law, 2013, p. 448-451.

Schwab, K., Novitskaya, N. (2007). Method of choice of taxpayers for documentary checks. World Finance, № 2, p. $85-92$.

\section{Богдан КОСТЮК}

МЕТОДИКА ПРОВЕДЕНИЯ НАЛОГОВОГО АУДИТА ОТДЕЛЬНЫХ КАТЕГОРИЙ ПЛАТЕЛЬЩИКОВ НАЛОГОВ ОРГАНАМИ ГОСУДАРСТВЕННОЙ ФИСКАЛЬНОЙ СЛУЖБЫ УКРАИНЫ

Аннотация. Целью работы является обобщение методики проведения налогового аудита отдельных категорий плательщиков налогов органами ГФС Украины. Предметом исследования являются методы проведения аудита органами ГФС Украины. Методика. При написании статьи использовались общие и специальные методы исследования, среди которых: анализ и синтез, системный и процессный подходы, индукция и дедукция и т. д. Результаты. Налоговый аудит является важным направлением и составляющей частью налогового контроля. Его основное назначение состоит в обеспечении контроля за соблюдением норм налогового законодательства про уплату налогов и сборов. Проблема развития организации налогового аудита в Украине состоит в разработке комплексного системного подхода и связанных с ним методических решений, которые были бы способны создать условия для их практической реализации. На жаль, вопросы практики использования налогового аудита еще недостаточно изучены. Сегодня основные принципы и особенности проведения налогового аудита рассматриваются отечественными учеными в основном в теоретической плоскости. Несмотря на существование методических рекомендаций по проверке того или иного вида налога, сбора, другого обязательного платежа, которые разработаны налоговой службой, вопросы формирования доказательной базы, порядок использования конкретных способов и приемов аудита, источника информации и т.д. остаются вне поля зрения как законодателей, так и ученых. Несмотря на это, сегодня именно налоговый аудит тот инструмент, который позволяет максимально точно изучить и снизить налоговые риски организации. Другая проблема налогового аудита состоит в том, что на законодательном уровне понятие «налогового аудита» не закреплено, соответственно отсутствует законодательное определение, которое приводит к неоднозначному трактованию его понятия. Налоговый аудит позволяет обеспечить более эффективное поступление налогов и сборов в бюджет страны. Хотя на сегодняшний день и повышается эффективность механизма проведения отечественного налогового аудита, но рядом с этим существует ряд проблем, которые необходимо решить с целью обеспечения более рационального поступления налогов в бюджет соответственно к современным условиям социально-экономических и политических преобразований в Украине. Для дальнейшего усовершенствования налогового аудита необходимо использовать новые, прогрессивные методы влияния на плательщиков, которые способствуют максимальному ограничению участия плательщика в налоговом процессе и в уменьшении его потенциальной возможности минимизации налоговых обязательств. Практическое значение исследования состоит в определении рекомендаций для усовершенствования методики отбора плательщиков налогов для проведения налоговых проверок. Значение/оригинальность. Полученная в ходе исследования информация о методике проведения налогового аудита может быть использована в процессе дальнейших исследований для усовершенствования налогового администрирования. 